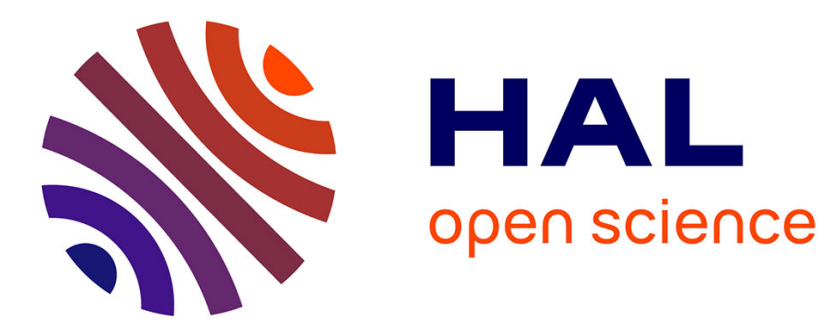

\title{
Geographic Variations, of the Large-Scale Vertical Exchange Speed
}

Ba Cuong Nguyen, Gérard Lambert, Nguyen Ba, C • Jong, Rard Lambert

\section{To cite this version:}

Ba Cuong Nguyen, Gérard Lambert, Nguyen Ba, C • Jong, Rard Lambert. Geographic Variations ,of the Large-Scale Vertical Exchange Speed. Journal of Geophysical Research, 1970, 75 (15), pp.28772884. 10.1029/jc075i015p02877 . hal-03403117

\section{HAL Id: hal-03403117 https://hal.science/hal-03403117}

Submitted on 26 Oct 2021

HAL is a multi-disciplinary open access archive for the deposit and dissemination of scientific research documents, whether they are published or not. The documents may come from teaching and research institutions in France or abroad, or from public or private research centers.
L'archive ouverte pluridisciplinaire HAL, est destinée au dépôt et à la diffusion de documents scientifiques de niveau recherche, publiés ou non, émanant des établissements d'enseignement et de recherche français ou étrangers, des laboratoires publics ou privés. 


\title{
Geographic Variations of the Large-Scale Vertical Exchange Speed
}

\author{
NguYen Ba Cuong and Gérard Lambert \\ Centre des Faỉbles Radioactivités, CNRS, Gif-sur-Yvette, France
}

\begin{abstract}
From a global study of the radioactive fallout in the latitude range $30^{\circ}-60^{\circ} \mathrm{N}$ during the period 1963 to 1967 five regularly spaced areas have been found in which the amount of nuclear debris is somewhat higher than the average. This phenomenon may be attributed to an inhomogeneity in the rates of exchange between the lower stratosphere and the mid-troposphere, possibly related to the standing waves of the polar jet stream. At lower altitudes the existence of a continental threshold layer, which is characterized by a lower coefficient of vertical exchange, gives rise to an excess of dry fallout over the oceans. This may explain the discrepancies in measurements of the amount of radioactive fallout over continental areas and over oceanic areas at the same latitude, as observed by various authors.
\end{abstract}

\section{Inhomogeneities in Radioactive Fallouts}

Most of the radioactive debris produced by large nuclear weapon tests in the atmosphere is immediately injected into the stratosphere. Fallout onto the earth's surface depends on the reinjection of radioactive aerosols into the troposphere and on washout by precipitation or dry deposit.

The atmospheric circulation is essentially zonal, especially at high altitudes. Therefore, a short time after a series of explosions, the concentration of radioactive aerosols in the stratosphere and in the higher troposphere is homogeneous at a particular altitude and latitude. On the earth's surface, the amount of long-lived radioactive debris varies with the latitude of the collection site. Many authors have also outlined the influence of the type and quantity of precipitations on the amount of fallout. We have shown that, independent of any considerations of altitude, the nearness of mountain masses could locally modify the rate of radioactive fallout [Nguyen $B a$ Cuong and Lambert, 1967].

If the results of the ${ }^{00} \mathrm{Sr}$ measurements made by the Health and Safety Laboratory [Hardy and Rivera, 1970] between $30^{\circ}$ and $60^{\circ} \mathrm{N}$ are investigated for a period of several years, five recurring zones of high-intensity fallout can be found. Figure 1 shows the mean annual fallout from 1963 to 1967, a period without any strong nuclear tests. The data are given for $10^{\circ}$ bands

Copyright (c) 1970 by the American Geophysical Union. of longitude. Three main peaks may be observed in the vicinity of $0^{\circ}, 80^{\circ}$, and $160^{\circ} \mathrm{W}$; two other peaks may be assumed to exist at $80^{\circ}$ and $160^{\circ} \mathrm{E}$ (There are not enough stations in the eastern hemisphere for more definite conclusions to be drawn.)

On the whole, these latitudinal variations differ from variations with amount of rainfall. As a matter of fact, it can be seen from Figure 2 that the mean values for rainfall and ${ }^{\circ} \mathrm{Sr}$ deposit (measured at the same stations) vary differently as a function of the longitude, except perhaps for the $130^{\circ}-170^{\circ} \mathrm{W}$ range.

It is possible, of course, to attribute this result to the more or less permanent distribution of cyclonic and anticyclonic areas around the earth. Nevertheless, the regular distribution of the maxima of radioactivity deposited suggests an oscillatory phenomenon. It may be recalled that, according to Rossby [1947], standing waves may exist for certain jet-stream velocities, the number of waves being greater when the jet speed is smaller. (The number of waves may vary from 3 to 8 .)

Reed and Danielsen [1959], Staley [1960], Reiter [1963a, b], Mahlman [1964], Queney [1965], Sheppard [1965], Nguyen Ba Cuong [1968], and others have established that one of the primary mechanisms of transport from the stratosphere to the troposphere results from the downward movements of stratospheric air associated with polar front jet streams. It is suggested by Figures 1 and 2 that jet-stream 
waves may carry away radioactive aerosols in a very strong downward motion, from the lower stratosphere to the middle troposphere, within well determined zones regularly situated around the earth. Some of these 'hot fallout areas' are continental and others are oceanic. Thus it seems possible to explain the discrepancies sometimes observed in the measurements of strontium fallout made by different authors working at about the same latitude but in different parts of the oceans or continents [e.g., Bowen and Sugihara, 1960; Rocco and Broecker, 1963; Shvedov et al., 1963; Karol et al., 1965; Broecker, 1966; Broecker et al., 1966; Chesselet, 1966; Volchok, 1966, 1967; Bowen et al., 1968, 1969].

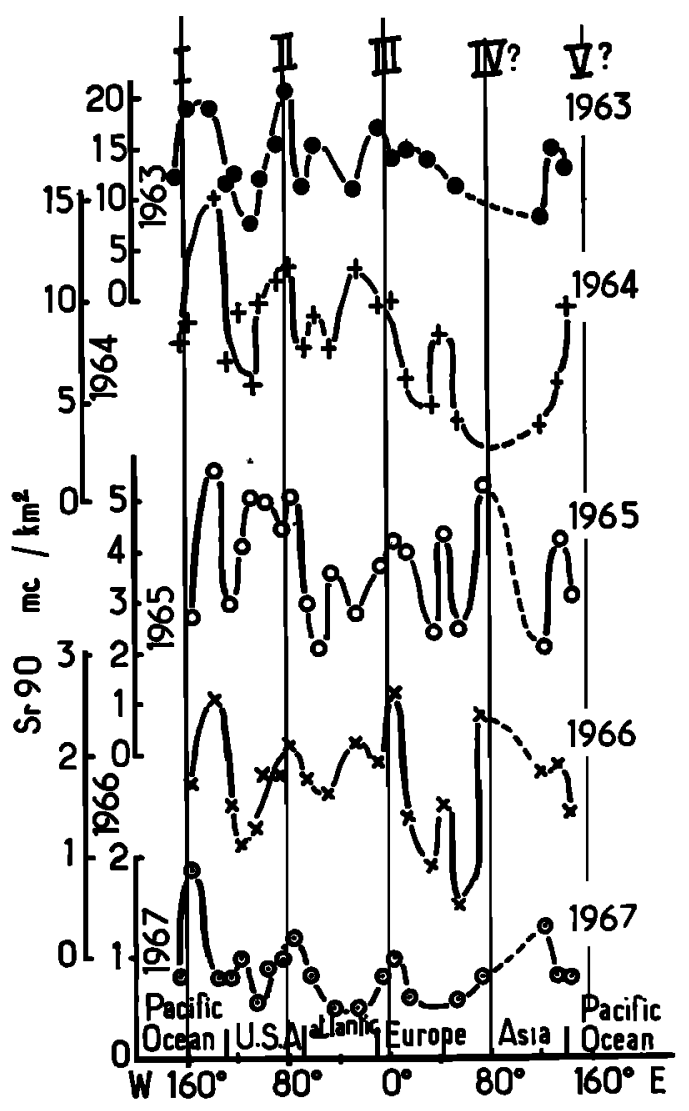

Fig. 1. Variation with longitude of yearly strontium 90 deposit between $30^{\circ} \mathrm{N}$ and $60^{\circ} \mathrm{N}$. Data include results from British stations given by Cambray et al. [1969].

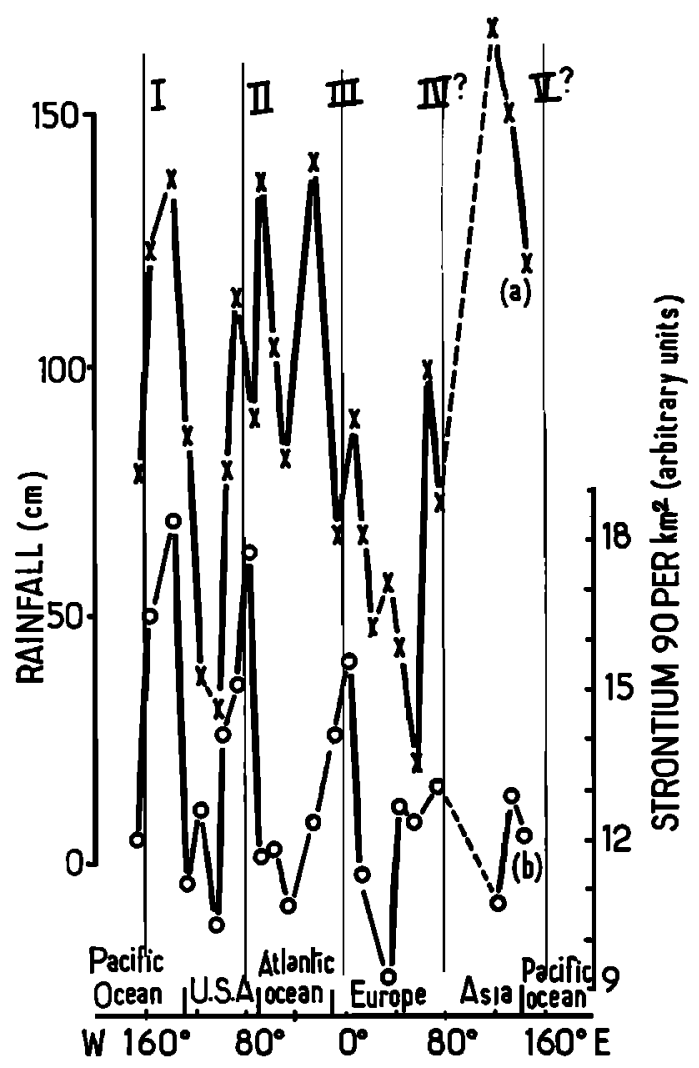

Fig. 2. Variation with longitude between $30^{\circ}$ and $60^{\circ} \mathrm{N}$. Curve $a$ is for average yearly rainfall from 1963 to 1967 . Curve $b$ is for strontium 90 deposit during the same period. The ${ }^{00} \mathrm{Sr}$ values are indicated in arbitrary units after normalization to the mean annual value for the United States for 1963.

\section{Bodndary Layer above Conttinents}

We have seen that it is difficult to compare the measurements of radioactive fallout over seas and over continents (on the earth's scale) even within a very limited band of latitude. However, it has been pointed out that in neighboring oceanic and continental areas some markedly different rates of fallout have been measured. Thus, Chesselet [1966] found 2 to 7 times more fallout in the sea water of the Bay of Biscaye than at the sampling stations situated on the surrounding coast. In the same way, we have compared the atmospheric concentrations of radioactive aerosols from artificial origin at stations on both sides of the region studied by Chesselet, (i.e., at point $\mathrm{K}, 45^{\circ} 00 \mathrm{~N}$, $16^{\circ} 00 \mathrm{~W}$ ) and at various French stations, Gif- 
TABLE 1. Average Monthly Cesium 137 Activity in the Air at Point $\mathbf{K}$ and at Continental Stations Values in $10^{-2} \mathrm{pc} / \mathrm{m}^{8}$.

\begin{tabular}{|c|c|c|c|c|c|c|c|c|c|}
\hline \multirow[b]{2}{*}{ Months } & \multicolumn{3}{|c|}{1964} & \multicolumn{3}{|c|}{1965} & \multicolumn{3}{|c|}{1966} \\
\hline & (1) & (2) & (R) & (1) & (2) & (R) & (1) & (2) & (R) \\
\hline Jan. & & & & 18.4 & 13.9 & 1.32 & & & \\
\hline Feb. & & & & 25.7 & 13.9 & 1.84 & 7.3 & 5.0 & 1.46 \\
\hline March & & & & 22.8 & 15.9 & 1.43 & 10.7 & 6.5 & 1.65 \\
\hline April & & & & 19.0 & 18.4 & 1.12 & 6.8 & 6.7 & 1.01 \\
\hline May & & & & & & & 9.2 & 9.1 & 1.01 \\
\hline June & & & & & & & & & \\
\hline July & & & & & & & 4.8 & 3.9 & 1.23 \\
\hline Aug. & & & & & & & 4.7 & 4.1 & 1.15 \\
\hline Sept. & & & & 5.0 & 3.7 & 1.35 & 3.8 & 1.9 & 2.00 \\
\hline Oct. & 14.6 & 11.6 & 1.26 & 5.6 & 5.0 & 1.12 & 2.8 & 2.4 & 1.17 \\
\hline Nov. & 12.9 & 10.4 & 1.24 & 3.8 & 3.3 & 1.15 & & & \\
\hline Dec. & 11.2 & 8.0 & 1.40 & & & & 2.3 & 1.3 & 1.77 \\
\hline
\end{tabular}

(1) Activity point $\mathrm{K}\left(16^{\circ} 00 \mathrm{~W}, 45^{\circ} 00 \mathrm{~N}\right)$.

(2) Mean activity of the stations at Gif-sur Yvette, La Rochelle and Monaco.

(R) Ratio of values in column 1 to values in column 2. Mean of $(R)=1.3$.

sur-Yvette (near Paris), LaRochelle, and Monaco. Table 1 shows that from 1964 to 1967 the mean monthly concentration of ${ }^{187} \mathrm{Cs}$ at point $\mathrm{K}$ was always higher than the mean value for the three continental French stations (on the average about 1.3 times higher). The concentration at point $K$ is comparable only to the value observed at the station situated at the top of the Pic du Midi (Table 2), 2860 meters above sea level.
This result means that, regardless of any climatological conditions (such as rainfall), the amount of radioactive material brought down at lower altitudes is greater at point $K$ (over the sea) than at stations on the neighboring continental plains. This fact is confirmed by the existence of air activity variations, which are large and quite similar at point $K$ and at high mountain stations, but which are much smaller over continental plains (Figure 3).

TABLE 2. Average Monthly Gross $\beta$ Activity in the Air at Point $K$ and at the Pic du Midi Station Values in $10^{-8}$ picarcuries/cubic meter

\begin{tabular}{|c|c|c|c|c|c|c|c|c|c|}
\hline \multirow[b]{2}{*}{ Months } & \multicolumn{3}{|c|}{1964} & \multicolumn{3}{|c|}{1965} & \multicolumn{3}{|c|}{1966} \\
\hline & (1) & (2) & (R) & (1) & (2) & (R) & (1) & (2) & (R) \\
\hline Jan. & & & & 0.24 & 0.22 & 1.09 & & & \\
\hline Feb. & & & & 0.39 & 0.36 & 1.08 & 0.08 & 0.08 & 1.00 \\
\hline March & & & & 0.35 & 0.28 & 1.25 & 0.13 & 0.17 & 0.76 \\
\hline April & & & & 0.33 & 0.19 & 1.74 & 0.09 & 0.10 & 0.90 \\
\hline May & & & & & & & 0.14 & 0.24 & 0.58 \\
\hline \multicolumn{10}{|l|}{ June } \\
\hline July & & & & & . & & 0.09 & 0.18 & 0.50 \\
\hline Aug. & & & & & & & 0.07 & 0.12 & 0.58 \\
\hline Sept. & & & & 0.10 & 0.10 & 1.00 & 0.06 & 0.07 & 0.86 \\
\hline Oct. & & & & 0.08 & 0.08 & 1.00 & 0.03 & 0.02 & 1.50 \\
\hline Nov. & 0.46 & 0.44 & 1.04 & 0.05 & 0.04 & 1.25 & 0.20 & 0.23 & 0.87 \\
\hline Dec. & 0.19 & 0.30 & 0.63 & & & & & & \\
\hline
\end{tabular}

(1) Activity at point $\mathrm{K}\left(16^{\circ} 00 \mathrm{~W}, 45^{\circ} 00 \mathrm{~N}\right)$.

(2) Mean activity at Pic du Midi $\left(42^{\circ} 56 \mathrm{~N}, 0^{\circ} 8 \mathrm{E}\right)$.

(R) Ratio of values in column 1 to values in column 2 . Total mean ratio is 0.98 . 


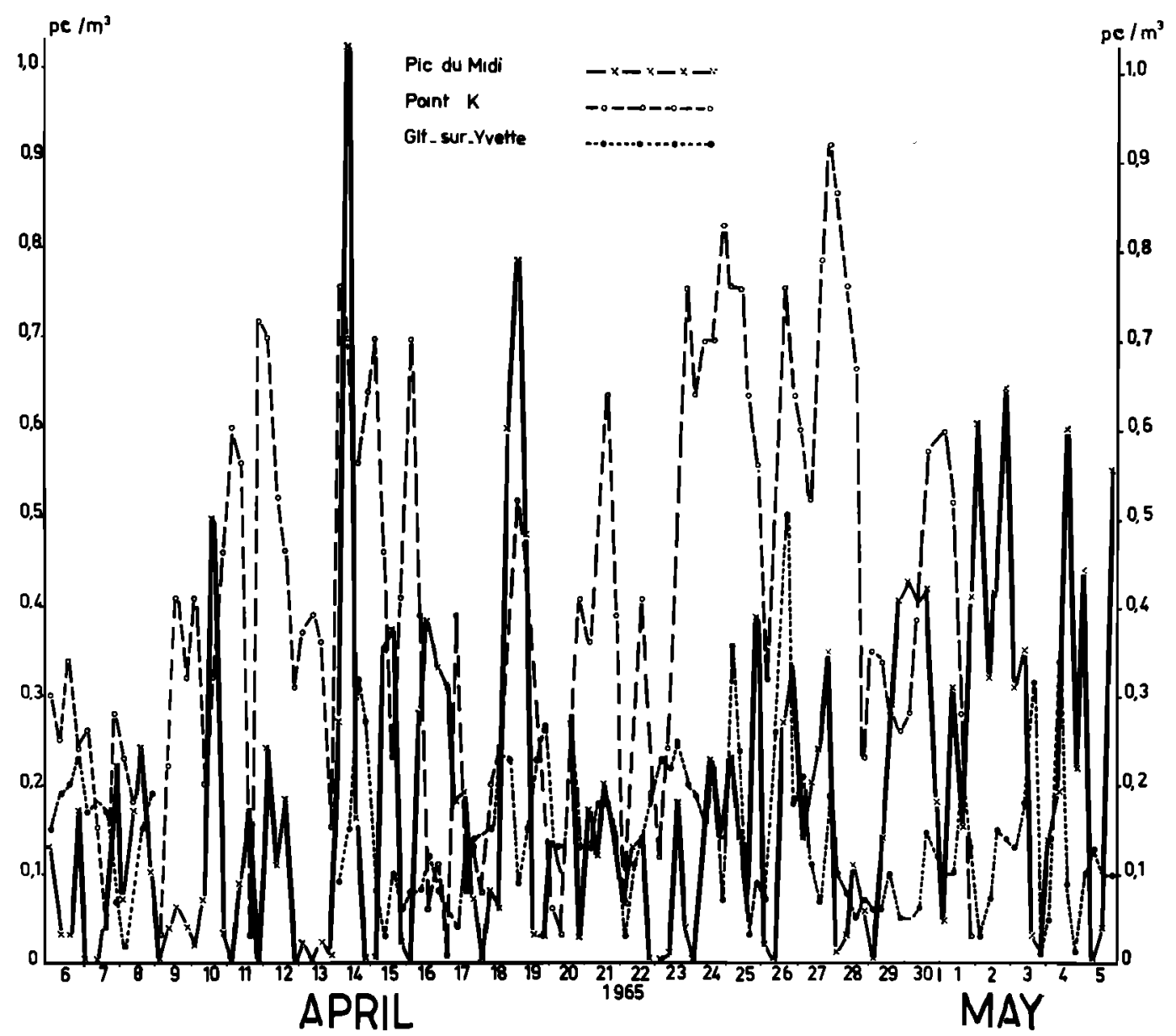

Fig. 3. Gross $\beta$ radioactivity of aerosols. Samples integrated over 6 hours.

This phenomenon may be explained by the existence over continents of a boundary layer, reaching an altitude of $2 \mathrm{~km}$, in which the vertical exchange would be smaller (Figure 4). This layer would also account for the following observations:

1. If we consider the activity of fission products in the air in 6-hour periods, it appears that the activity is about 1.3 times greater between noon and 6 P.M. than between midnight and 6 A.M. This result is not evident in a daily monitoring but appears clearly in the monthly mean values. Figure 5 shows the mean relative air activity at Gif-sur-Yvette during 1964 for each of the 6-hour samples. It can be seen from the figure that the time of maximum activity coincides with a well marked maximum in the yearly average wind speed (as recorded at Orly, $15 \mathrm{~km}$ away) and consequently coincides with a higher eddy diffusion coefficient. Similar results were obtained in 1965 and 1966.

2. If a discontinuity exists in the downward exchange velocities (fission products), it must also appear in the upward transfer of natural radioactive products issued from the soil. After measuring radon concentrations as a function of altitude both over the Atlantic Ocean and over the Parisian region, Nguyen Ba Cuong and Lambert [1967] have shown that the radon concentration measured over the Atlantic (400 $\mathrm{km}$ west of Brest) is almost constant in the altitude range of 700 to 4300 meters. In the Parisian region, however, in November (when the atmosphere was clear) the radon concentration gradient showed a sharp variation near 


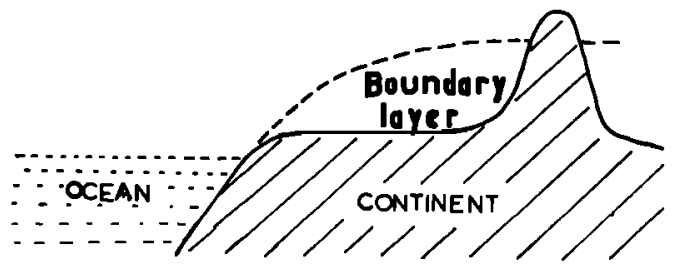

Fig. 4. Schematic drawing of continental boundary layer.

the altitude of 2000 meters at the border between two air layers, one of which was thermally stable and the other thermally unstable. Fontan et al. [1968] found the same results in Toulouse for various seasons. It is interesting to note that this vertical structure seems to be preserved over the entire Euro-Asiatic continental mass. Similar measurements have been made by Kirichenko [1964] over the USSR.

It would therefore appear that a boundary layer exists in the first $2 \mathrm{~km}$ of altitude above the continents, in which, as a consequence of the slowing down of winds and despite possible thermal instabilities, vertical exchange movements are very markedly hampered.

The slowing down of the vertical exchange at lower altitudes over continents results in a decrease in fallout per unit area; the aerosols that had no time to reach the ground are carried away by the general circulation and will later constitute an additional fallout for the ocean surface. A calculation of this sort may be attempted only for dry fallout, although it necessitates, for each zone of the atmosphere, a good knowledge of the vertical exchange coefficient, whose processes are poorly known. Various authors, utilizing either humidity or temperature as a tracer, or making use of the presence of radon and thoron, have measured these exchange velocities, which are expressed in the form of a vertical eddy diffusion coefficient (see Table 3). On the average, for continents a value (assumed to be uniform) of $5 \times 10^{5}$ $\mathrm{cm}^{2} \mathrm{sec}^{-1}$ may be adopted above $2 \mathrm{~km}$, and only $1 \times 10^{5} \mathrm{~cm}^{2} \mathrm{sec}^{-1}$ below this altitude. For seas it seems reasonable to adopt, even at lower altitudes, the value of $5 \times 10^{5} \mathrm{~cm}^{2} \mathrm{sec}^{-1}$ (see Table $3)$.

The aerosols captured by precipitations will be very rapidly deposited on the earth's surface. If $\sigma$ is the probability of capture per unit time of aerosol particles having concentration $C$, we may write

$$
\frac{\partial C}{\partial t}=\frac{\partial}{\partial z}\left(K \frac{\partial C}{\partial z}\right)-\sigma C
$$

where $z$ designates the altitude measured positive downward from level $H(2 \mathrm{~km})$ and $K$ is the vertical eddy diffusion coefficient.

The disappearance of radioactive aerosols by disintegration may be neglected, owing to the length of their radioactive periods. We assume that $\sigma$ is uniform throughout the $0-$ to $2-\mathrm{km}$ altitude zone, without distinguishing between oceanic and continental regions. This assumption is probably incorrect, but, in any case, the range of values of $\sigma$ over oceans and continents is certainly not so wide as the range of values for coefficient $K$ (a factor 5). In the steady state, equation 1 becomes

$$
K \partial^{2} C / \partial z^{2}-(\sigma C)=0
$$

In the absence of a retransmission of aerosols from the surface, where they were deposited, the solution of this well-known equation will be in the form

$$
C(z)=C(H) \exp \left[-(\sigma / K)^{1 / 2} z\right]
$$

It may be seen that the mean values observed for the radioactive concentrations over oceans

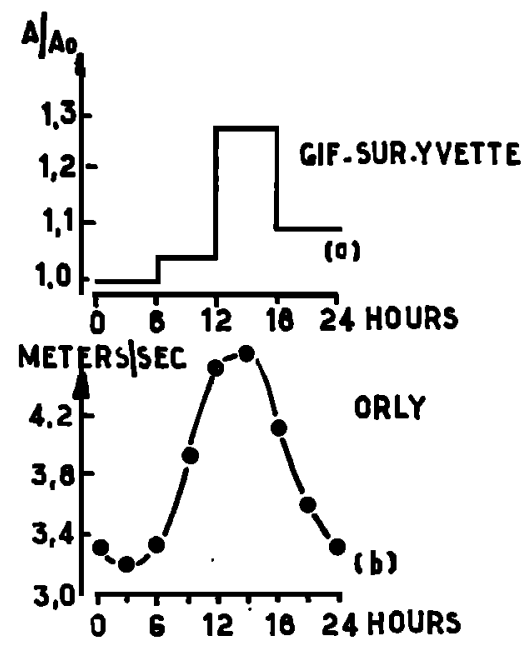

Fig. 5. (a) Mean 1964 values for diurnal variation of the relative air $\beta$ activity $A_{0}$ is activity between 0 and 6 A.M.; $A$, activity during the other 6-hour periods. (b) Wind diurnal variation in 1964 . 


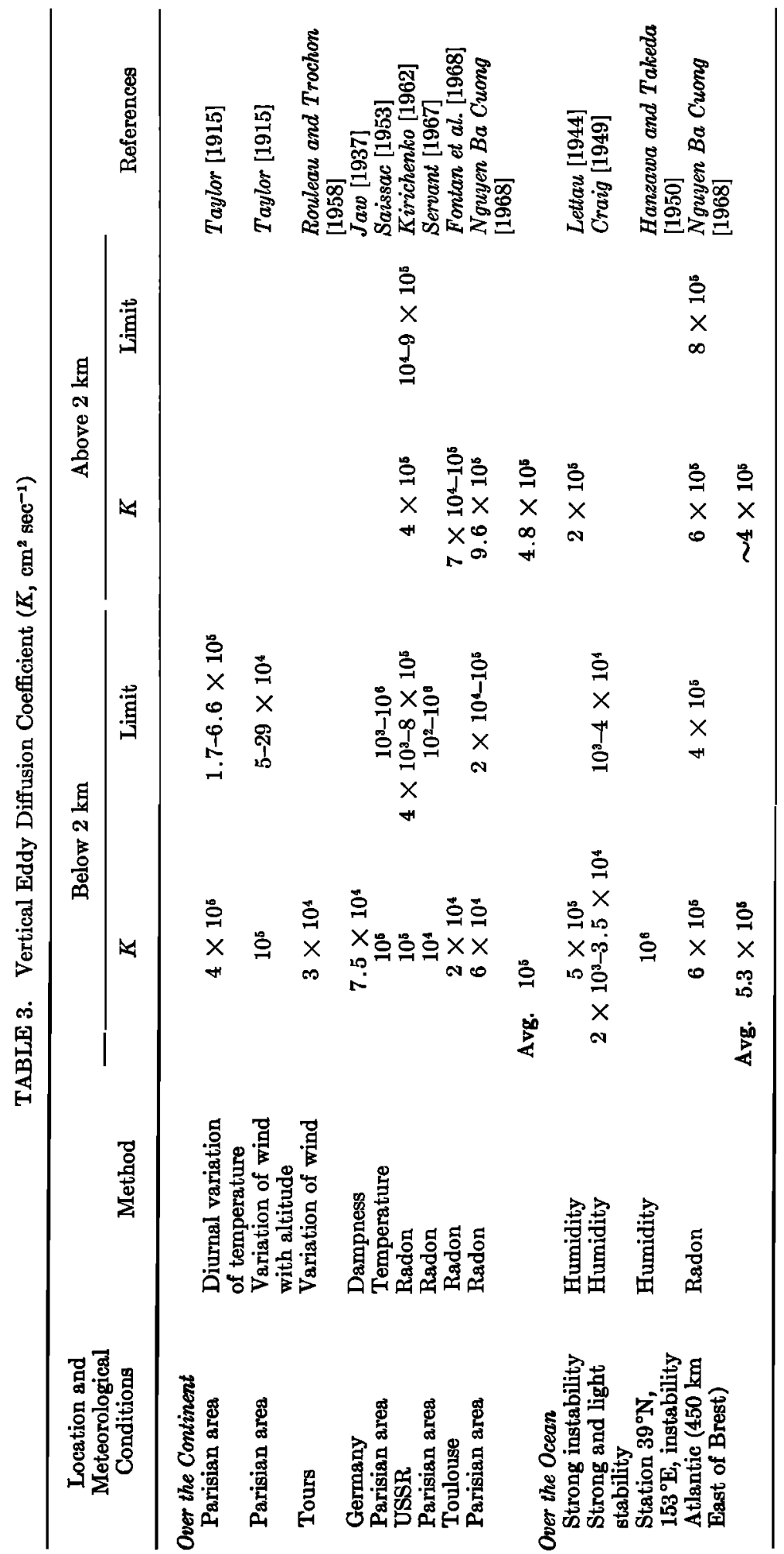


$C_{o}$ and over continents $C_{0}$ must be different. Their ratio may be calculated from equation 2 :

$$
\frac{C_{o}}{C_{c}}=\frac{\exp \left[-\left(\sigma / K_{o}\right)^{1 / 2} z\right]}{\exp \left[-\left(\sigma / K_{c}\right)^{1 / 2} z\right]}
$$

Between 1964 and 1966 the ratio $C_{o} / C_{0}$ was measured to be 1.3 for the ${ }^{15 \pi} \mathrm{Cs}$ concentrations at point $\mathrm{K}$ and in the plain regions situated in France (see Table 1). From this ratio $\sigma=$ $27 \times 10^{-3} \mathrm{sec}^{-1}$ was calculated, which corresponds to a mean residence time $(\tau=1 / \sigma)$ of 40 days, a very likely value.

This difference between $C_{0}$ and $C_{0}$ indicates a difference between the vertical fluxes of aerosols, i.e. between the dry fallouts per unit surface on continents and oceans. Effectively, according to Fick's law, the vertical eddy diffusion velocity of noncaptured aerosols will be

$$
v=-K / C \partial C / \partial z
$$

from which we find

$$
v=(\sigma K)^{1 / 2}=\text { const. }
$$

An air mass circulating round the earth will, in turn, pass over oceans and continents. Let $S$ be the speed and $L$ be the length of the transit over a continent or an ocean. The transit time will be $T=L / S$. The number of aerosol particles deposited at the surface of the region under study will be $Q=v C T$. For an air stream of unit width, dry fallout per unit surface will be proportional to $v C T / L$. The ratio of dry fallouts per unit surface of ocean and continent will therefore be

$$
R_{o / \mathrm{c}}=\frac{C_{\mathrm{o}}}{C_{\mathrm{c}}} \frac{S_{\mathrm{c}}}{S_{\mathrm{o}}}\left(\frac{K_{\mathrm{o}}}{K_{\mathrm{c}}}\right)^{1 / 2}
$$

In the $40^{\circ}$ to $50^{\circ}$ band of northern latitudes, where fallout has been the greatest, it may be stated that, on the average, between 0 to 2 $\mathrm{km}, S_{c} / S_{o}$ is about 0.7 . The $S_{o} / S_{o}$ ratio is deduced from wind data at $850 \mathrm{mb}$, available in 1965 and 1966 for Trappes (near Paris) and point K. From these data we find $R_{o / \theta}$ to be about 2.

Thus, without introducing any particular assumption on the direct exchange processes between the atmosphere and the ocean surface, the dry fallout rate over oceans may be estimated at twice the value measured over continents. One must recall, however, that for nuclear debris dry fallout represents only a fraction of total radioactive fallout, of the order of $20 \%$.

\section{Conclusions}

It may be considered that in the stratosphere radioactive fragments originating from nuclear explosions spread out rapidly and homogeneously for a constant altitude and latitude. Yet, in the troposphere, the variations in the vertical exchange velocities created by jet-stream waves or cyclogenesis associated with polar front jet stream or by the presence of a boundary layer, which over continents is approximately $2 \mathrm{~km}$ thick, give rise to considerable inhomogeneities in the distribution of radioactive fallout.

In addition there are the climatological factors that enhance the inhomogeneities of aerosol concentrations as a result of the very uneven washing of the atmosphere by precipitation, even in adjacent regions. Thus, the ascending motions that occur at the seaside and moreover the motions above relief appreciably alter the abundance of precipitations as well as the concentration of radioactive fragments. It should be pointed out, however, that in the calculations made in this paper the eddy diffusion coefficient and the wind speed were assumed to be constant over the vast expanse of an ocean, even though such homogeneity certainly is not the case.

Under these conditions, it is understandable that observers working in different regions will measure fairly variable fallout rates. The fact remains, in all cases, that we have advanced a model from which it is found that on the average radioactive fallout per unit surface should be slightly lower on continents than on the whole of the bordering oceans.

\section{REFERENCES}

Bowen, V. T., V. E. Noshkin, H. L. Volchok, and T. T. Sugihara, Fallout strontium $\mathbf{9 0}$ in Atlantic Ocean surface waters, Fallout program quarterly report, Health and Safety Lab. Rep. 197, 12-165, July 1, 1968.

Bowen, V. T., V. E. Noshkin, H. L. Volchok, and T. T. Sugihara, Strontium 90: Concentrations in surface waters of the Atlantic Ocean, Science, 164, 825-827, 1969.

Bowen, V. T., and T. T. Sugihara, Strontium 90 in 'mixed layer' of the Atlantic Ocean, Nature, 186, 71-72, 1960.

Broecker, W. S., Radioisotopes and the rate of mixing across the main thermoclines of the ocean, J. Geophys. Res., 71, 5827-5836, 1966. 
Broecker, W. S., E. R. Bonebakker, and G. G. Rocco, The vertical distribution of cesium 137 and strontium 90 in the oceans, 2, J. Geophys. Res., 71, 1999-2003, 1966.

Broecker, W. S., G. G. Rocco, and H. L. Volchok, Strontium-90 fallout: Comparison of rates over ocean, and land, Science, 152, 639-640, 1966.

Cambray, R. S., E. M. Fisher, W. L. Brooks, and D. H. Peirson, Deposition data from Midford Haven and from Abington, Radioactive fallout in air and in rain: Results to the middle of 1969, Health Physics and Medical Division, U.K. Atomic Energy Agency Research Group, Atomic Energy Research Establishment, Harwell, Nov. 1969.

Chesselet, R., Etude de la radioactivité artificielle du milieu marin par spectrométrie $\gamma$, Thesis, Faculté des Sciences de Paris, France, 1966.

Craig, R. A., Vertical eddy transfer of heat and water vapor in stable air, J. Meteorol., 6, 123$133,1949$.

Fontan, J., A. Birot, D. Blanc, and A. Bouville, Mesure de la concentration du radon dans la troposphère entre 0 et 5000 mètres d'altitude, Colloque Electronique et Radioactivité de l'Air, Communication, Toulouse, France, March 1968.

Hanzawa, M., and N. Takeda, Preliminary report on the transformation of the Siberian p.c. airmass traveling over sea in winter, Oceanogr. Mag. Tokyo, 2, 69-75, 1950.

Hardy, E. P., and J. Rivera, Strontium 90 and strontium 89 in monthly deposition at world land sites, Fallout program quarterly report, Health and Safety Lab. Rep. 217, A1-A288, Jan. 1, 1970.

Jaw, J., Zur Thermodynamik der Passatgrundströmung Veröffentl, Meteorol. Inst., Univ. Berlin, 2, 6, 1937.

Karol, I. L., Yu. V. Krasnopevtsev, V. D. Vilenskii, and S. G. Malakhov, Comparative analysis of nuclear explosion product global fallouts on continents and oceans, State Committee on the Use of Atomic Energy USSR, Moscow, 1965. (Translation, USSR reports on fallout over the oceans, Health and Safety Lab. At. Energy Comm. New Y'ork, 1-21, 1966.)

Kirichenko, L. V., The vertical distribution of the product of decay of radon in the free atmosphere, in Problems of Nuclear Meteorology, edited by I. L. Karol and S. G. Malakhov, State Publishing House for Literature in the Field of Atomic Science and Engineering, Moscow, 1962. (Translation series, U. S. At. Energy Comm. $A E C-t r-6128$, Meteorology (TID-4500, 25th ed.) pp. 92-124, 1964.)

Lettau, H., Die thermodynamische Beeinflussung arktischer Luftmassen über warmen Meeresflächen als Problem der meteorologischen Strōmmungs-u. Turbulenzlehre, Schr. Deut. LuftfahrtForschung, 8(3), 85-115, 1944.

Mahlman, J. D., Relation of stratospheric-tropospheric mass exchange mechanisms to surface radioactivity peaks, Colorado State Univ. Atmos. Sci. Tech. Pap. 58, 1964.
Nguyen $\mathrm{Ba}$ Cuong, Etude par les traceurs radioactifs des échanges entre les diverses zones de l'atmosphère au-dessus des continents et des océans, Thesis, Faculté des Sciences de Paris, France, 1968.

Nguyen Ba Cuong, and G. Lambert, Rôle du relief dans le taux de retombées radioactives, Géochimie, Précipitations, Evaporation, Humidité du Sol, Hydrométrie, pp. 203-214, Congrès de l'U.G.G.I., Berne (Switzerland), 1967.

Queney, P., Rôle des 'Jet-streams' dans les éxchanges entre la troposphère et la stratosphère, Colloque Electronique et Radioactivité de l'Air, 102-112, Feb. 1965.

Reed, R. J., and E. F. Danielsen, Front in the vicinity of the tropopause, Arch. Meteorol. Geophys. Bioklimatol., 11, 1-17, 1959.

Reiter, E. R., Jet Stream Meteorology, 515 pp., University of Chicago Press, Chicago, Ill., 1963a.

Reiter, E. R., A case study of radioactive fallout, J. Appl. Meteorol., 2, 691-705, $1963 b$.

Rocco, G., and W. S. Broecker, The vertical distribution of cesium 137 and strontium 90 in the oceans, J. Geophys. Res., 68, 4501-4512, 1963.

Rossby, C. G., On the general circulation in middle latitudes, Bull. Amer. Meteorol. Soc., 28, 255-280, 1947.

Rouleau, J., and R. Trochon, Météorologie Générale, Tome II, 178 pp., Paris, Ed. GauthierVillars, 1958.

Saissac, J., Mesure de la diffusivité turbulente dans l'atmosphère, J. Sci. Meteorol., Paris, no. $18,49-56,1953$.

Servant, J., La détermination du coefficient de diffusion turbulente verticale dans la basse atmosphère à l'aide du radon et ses dérivés à vie courte, La Météorologie, 3-12, Jan. 1967.

Shvedov, V. P., V. P. Patin, S. A. Maksimova et al., The strontium 90 content of the Black Sea in 1959-1961, Report of the State Committee for the Use of Atomic Energy in the USSR, Moscow, U.N. Doc. A/AC/82/G/L 909, 1963.

Sheppard, P. A., Transfer processes between the stratosphere and troposphere, Colloque sur les problèmes météorologiques de la stratosphère et de la mesosphère, Paris, France, March 1965.

Staley, D. O., Evaluation of potential-vorticity changes near the tropopause and the related vertical motions, vertical advection of vorticity, and transfer of radioactive debris from stratosphere to troposphere, J. Meteorol., 17, 591-620, 1960.

Taylor, G. I., On eddy motion in the atmosphere, Phil. Trans. Roy. Soc. London, A, 215, 1-26, 1915.

Volchok, H. L., The global strontium 90 budget, J. Geophys. Res., 71, 1515-1518, 1966.

Volchok, H. L., Strontium 90 deposition in the Atlantic Ocean, Fallout program, quarterly report, Health and Safety Lab. Rep. 181, 125-130, April 1, 1967.

(Received November 12, 1969 ; revised February 20, 1970.) 